\title{
Possibility of inducing tumor cell senescence during therapy (Review)
}

\author{
GUOHUI WANG, XIANLIANG CHENG, JINGYI ZHANG, YUAN LIAO, YINNONG JIA and CHEN QING \\ School of Pharmaceutical Sciences and Yunnan Provincial Key Laboratory of Pharmacology for \\ Natural Products, Kunming Medical University, Kunming, Yunnan 650500, P.R. China
}

Received December 10, 2019; Accepted February 17, 2021

DOI: $10.3892 / \mathrm{ol} .2021 .12757$

\begin{abstract}
The treatment options for cancer include surgery, radiotherapy and chemotherapy. However, the traditional approach of high-dose chemotherapy brings tremendous toxic side effects to patients, as well as potentially causing drug resistance. Drug resistance affects cell proliferation, cell senescence and apoptosis. Cellular senescence refers to the process in which cells change from an active proliferative status to a growth-arrested status. There are multiple factors that regulate this process and cellular senescence is activated by various pathways. Senescent cells present specific characteristics, such as an increased cell volume, flattened cell body morphology, ceased cell division and the expression of $\beta$-galactosidase. Tumor senescence can be categorized into replicative senescence and premature senescence. Cellular senescence may inhibit the occurrence and development of tumors, serving as an innovative strategy for the treatment of cancer. The present review mainly focuses on senescent biomarkers, methods for the induction of cellular senescence and its possible application in the treatment of cancer.
\end{abstract}

Correspondence to: Dr Yinnong Jia or Professor Chen Qing, School of Pharmaceutical Sciences and Yunnan Provincial Key Laboratory of Pharmacology for Natural Products, Kunming Medical University, 1168 West Chunrong Road, Chenggong, Kunming, Yunnan 650500, P.R. China

E-mail: jiayinnong@outlook.com

E-mail: qingchenhh@yeah.net

Abbreviations: SA- $\beta$-gal, senescence-associated $\beta$-galactosidase; CDK, cyclin dependent kinase; SASP, senescence-associated secretory phenotype; ROS, reactive oxygen species; ATM, ataxia telangiectasia mutated; $16^{\mathrm{INK} 4 \mathrm{a}}, \mathrm{CDK}$ inhibitor $2 \mathrm{~A} ; \mathrm{Rb}$, retinoma inhibitory protein; $\mathrm{pRb}, \mathrm{Rb}$ protein; Skp2, S-phase kinase-associated protein 2; $\mathrm{PKC}$, protein kinase $\mathrm{C}$; $\mathrm{CHK}$, checkpoint kinase

Key words: tumor cell senescence, p53, pRb. senescent biomarker, treatment

\section{Contents}

1. Introduction

2. The phenomenon of tumor cellular senescence

3. Senescence biomarkers

4. Cell cycle regulation in tumor senescence

5. Causes of cell senescence

6. Senescence induction pathways

7. Conclusions

\section{Introduction}

Cancer has high incidence and mortality rates worldwide. Tumor cells can easily develop resistance to traditional treatments, and survive to result in metastasis and invasion. The induction of tumor senescence has been proposed as a potential method for the treatment of tumors. In 1961, Hayflick and Moorhead (1) cultured human fibroblasts and found that normal diploid cells proliferated in vitro for 50-70 generations before entering senescence. This limit to cell proliferation, when cells lose their proliferative ability but maintain stable metabolic activity, is called the 'Hayflick Limit'. After reaching this limit, the cells enter into a senescent state (2). Senescence is a defensive mechanism that prevents cells from being damaged. When cells are senescent, they do not re-enter the cell cycle when exposed to mitogenic stimuli, but exhibit an enhanced secretory phenotype and are resistant to cell death. It has been hypothesized that cell senescence is an important mechanism that may be used to attack tumorigenic cells. When DNA is damaged, cell senescence becomes the third pathway, in addition to apoptosis and DNA repair, to defend against tumorigenesis (3). Some antitumor drugs have been demonstrated to inhibit tumor cell proliferation by inducing senescence in vitro and in vivo $(4,5)$. Therefore, the induction of cancer cell senescence and the subsequent inhibition of tumorigenesis and recurrence is a focus of research into novel tumor treatments

Tumor senescence can be divided into two types, namely replicative senescence and premature senescence. Replicative senescence is determined by the number of cell divisions (6). Premature senescence is mainly caused by DNA damage, the loss of tumor suppressor factors, oxidative stress and malnutrition $(7,8)$. 
Tumor cells exhibit unique characteristics when senescent, the most notable being the loss of ability to proliferate in an unlimited capacity whilst maintaining metabolic activity (9). Senescent cells are usually arrested in the $G_{0}$ or $G_{1}$ phase $(10,11)$. Research has focused on studying the phenotypical characteristics of cells after they have entered senescence, as well as the mechanisms of action that activate the process and the molecular signaling pathways involved (12). In subsequent sections of the present review, the factors that initiate senescence and induce senescent phenotypes are discussed.

\section{The phenomenon of tumor cellular senescence}

When tumor cells enter into senescence, they exhibit morphological changes, including an increase in volume, flattened shape and increased intercellular space, and they also present with blocked DNA synthesis, heterochromatin foci, lipofuscin accumulation, DNA damage-induced foci, loss of lamin B1, satellite distension, the expression of differentiated embryonic chondrocyte-expressed 1 and decoy death receptor 2 , the upregulation of certain microRNAs and secretion of numerous factors, including growth factors, cytokines, chemokines and proteases, which are collectively known as the senescence-associated secretory phenotype (SASP) (5,13-17). The SASP has been shown to contribute to the protective effect of senescence, and to induce detrimental effects when the pathological accumulation of senescent cells occurs. One study revealed that cisplatin can induce HepG2 tumor cells to enter into senescence and present senescent phenotypes, even when used at a low dose (18). Such effects of this and other chemotherapeutic agents have been confirmed in numerous cell lines, including HCT-116, H460, H1299, HT1080 and A549 $(19,20)$. For example, Zhang et al (20) treated HCT-116 colon cancer cells with 20 and $50 \mathrm{nM}$ camptothecin for $24 \mathrm{~h}$, and the cells entered into senescence $48 \mathrm{~h}$ after the low-dose treatment. Also, when treated with a low level of DNA-damaging agents, such as cisplatin and doxorubicin, HepG2 cells clearly progressed into senescence $(18,21,22)$. At present, several anticancer drugs that are used clinically are known to mediate therapy-induced senescence, including docetaxel, bleomycin, cyclophosphamide, doxorubicin, vincristine, etoposide and cisplatin; all of the aforementioned chemotherapeutic agents have been shown to induce senescence in various cancer cell lines (23).

\section{Senescence biomarkers}

When cells enter senescence, certain markers are expressed, such as senescence-associated $\beta$-galactosidase (SA- $\beta$-gal). SA- $\beta$-gal has been identified as a specific marker for cell senescence, as it is detected by histology in the majority of senescent cells, but not present in non-senescent cells (24). Senescent cells can also be recognized using physiological methods, such as measurement of the formation of senescence-associated heterochromatin foci and SASP-associated factors (25). Another marker commonly used to identify senescent cells is the cyclin-dependent kinase inhibitor $2 \mathrm{~A}$ (p16 $6^{\mathrm{INK} 4 \mathrm{a}}$ ) tumor suppressor protein, which is expressed at a low level or is undetectable in the majority of healthy cells and tissues, but is notably upregulated in most senescent tumor cells $(21,26)$. The identification of novel markers of senescence may assist in the prognosis of senescence and cancer. Various other biomarkers of senescence have been identified and are listed in Table I (27-41).

\section{Cell cycle regulation in tumor senescence}

Regulation of the cell cycle is a complex progress, which controls basic activities including growth, division and differentiation (42). Cell division genes control the initiation and progression of the cell cycle, and two tumor suppressor genes, namely retinoma inhibitory protein $(\mathrm{Rb})$ and $\mathrm{p} 53$, have important roles in cell cycle arrest and the maintenance of senescence (43). The $\mathrm{Rb}$ protein $(\mathrm{pRb})$ is critical for the $\mathrm{G}_{1} / \mathrm{S}$ and $\mathrm{G}_{2} / \mathrm{M}$ regulatory points of the cell cycle; when activated through dephosphorylation it leads to the transcription of S-phase genes being blocked (44). Tumor cell senescence is also induced by p53 following treatment with chemotherapeutic drugs, which results in cell cycle arrest in the $G_{1} / S$ and $\mathrm{G}_{2} / \mathrm{M}$ phases $(45,46)$. In addition, some cyclin-dependent kinase (CDK) 4/6 inhibitors, including palbociclib and amebaciclib, have also been demonstrated to induce senescence. Currently, these drugs have been approved for clinical, to be used alone or in combination, for chemotherapy (47-49).

\section{Causes of cell senescence}

Effects of telomeres and telomerase. Telomere-induced cell senescence is a component of replicative senescence. As the telomeres of normal cells shorten, the cells eventually undergo a stagnation of proliferation or division and reach senescence. By contrast, tumor cells often exhibit unlimited proliferative capacity, because the length of telomeres in tumor cells is stable (Fig. 1) (44,50,51).

Telomerase is a reverse transcriptase, the main function of which is to add the repeat base sequence TTAGGG to the end of chromosomes to increase the length of telomeres and the number of cell divisions $(9,52)$. One study demonstrated that the telomeres of human primary fibroblasts shorten when the cells lose their proliferative capacity (53). However, the cell senescence caused by telomere shortening can be prevented via the activation of telomerase (51). Telomerase serves an important role in the process by which cells escape senescence, as its activation can stabilize the length of telomeres and even prolong the life of tumor cells. Among the 100 immortalized cell lines tested by Kim et al (54), telomerase was highly expressed in 94 tumor-derived cell lines.

Due to the complexity of telomerase, various strategies for its inhibition have been developed as potential treatments for cancer. These include the use of antisense oligonucleotides to target the RNA component of telomerase, chemical telomerase inhibitors, oligonucleotides and nucleosides, small-molecule drugs that target human telomerase reverse transcriptase (TERT), gene therapies, and molecules that target telomeres and telomerase-related proteins (17,55-59). Among these, a non-competitive inhibitor of TERT, BIBR1532, has been demonstrated to shorten telomere length, inhibit cell proliferation and induce senescence in human cancer cells (60). The aforementioned studies have shown that telomerase dysfunction can induce cell senescence, 
Table I. Biomarkers used in the detection of cell senescence.

\begin{tabular}{llr}
\hline Senescence biomarker & \multicolumn{1}{c}{ Biomarker category } & $($ Refs.) \\
\hline SA- $\beta$-Gal & Senescence-associated $\beta$-galactosidase & $(5,27-29)$ \\
SAHF & Senescence-associated heterochromatic foci & $(28,30,31)$ \\
p21 $1^{\text {WAF1/CIP1 }}$ & CDK inhibitor & $(21,32,33)$ \\
p16 & CDK 4 inhibitor & Marker of DNA damage and repair \\
$\gamma$-H2AX & CDK inhibitor & $(36,34,35)$ \\
ARF & Senescence-associated secretory phenotype factors \\
SASP factors & $(35,38,39)$ \\
\hline
\end{tabular}

SA- $\beta$-gal, senescence-associated $\beta$-galactosidase; SAHF, senescence-associated heterochromatic foci; CDK, cyclin-dependent kinase; p21 ${ }^{\text {WAFI/CIP1 }}$, CDK inhibitor 1; p16 ${ }^{\text {INK4a }}$, CDK inhibitor 2A; SASP, senescence-associated secretory phenotype; $\gamma$-H2AX, $\gamma$-H2A histone family member X; ARF, ADP-ribosylation factor.

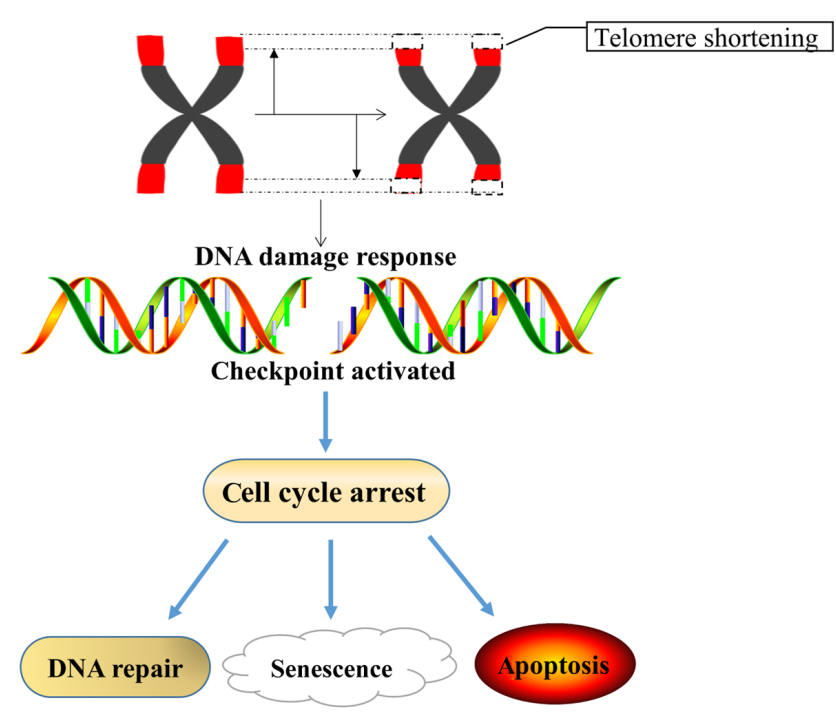

Figure 1. Telomere shortening causes cellular DNA damage, which induces cell senescence (replication senescence).

damage organ functions and shorten the human life span. However, the process of senescence may be reversed by inhibiting telomerase activation (61).

Effects of reactive oxygen species (ROS). The levels of active oxygen free radicals within living organisms increases over time (62). When free radicals are present in excessive quantities or the antioxidant capacity is inadequate, oxygen free radicals oxidize unsaturated fatty acids in cells, causing lipid peroxidation and biofilm damage, thus damaging the structure and function of organelles (63). The effects of ROS on cells are positively associated with their concentration. ROS attack mitochondrial DNA and accelerate the process of tumor cell senescence. The premature senescence of human fibroblasts occurs in a high-oxygen environment $\left(40-50 \% \mathrm{O}_{2}\right)$, while the cell cycle is extended in hypoxic conditions $\left(2-3 \% \mathrm{O}_{2}\right)(64,65)$. ROS intervene in tumor senescence through processes such as lipid peroxidation, DNA damage and protein destruction (66). Busulfan has been demonstrated to create DNA-DNA and DNA-protein cross-links, and induce the senescence of human fibroblasts in a ROS-dependent manner (67).
Multiple factors causing DNA damage and gene mutation. When tumor cells are exposed to abnormal external conditions but are unable to activate their auto-repair mechanisms, they may undergo senescence or apoptosis (68). Numerous types of antitumor treatment, including cytotoxic chemotherapy drugs, ionizing radiation and topoisomerase inhibitors, are DNA-damaging agents that can induce the senescence of tumor cells and as well as healthy cells (69-72). It has been shown that chemotherapeutic compounds, such as doxorubicin, etoposide and cisplatin, which cause double or single-strand breakages of DNA, can cause healthy human fibroblasts to become senescent prematurely $(73,74)$.

The activation of oncogenes in mammalian cells results in proliferative stress and the induction of senescence, which limits tumor growth. Genetic mutations can occur at any stage of development, usually during DNA replication or the interphase of cell division, and may affect DNA replication, DNA damage repair, carcinogenesis and senescence (75). Severe deficiencies in proteins that contribute to the sensing of DNA damage and its repair have the potential to accelerate senescence, while milder mutations in these same pathways may predispose individuals to develop cancer $(76,77)$. In young human fibroblasts, mutation of the Ras gene has been shown to induce cell cycle arrest in the $G_{1}$ phase, a senescence-like phenotype and SA- $\beta$-Gal expression $(78,79)$. Thus, senescence is a physiological mechanism of tumor suppression that inhibits the progression from benign tumor lesions to malignant tumors. In addition to the aforementioned factors, certain cellular pathways are also able to induce cell senescence.

\section{Senescence induction pathways}

Ataxia telangiectasia mutated (ATM), p53 and p21. Genes such as p53, p21 (CDK inhibitor 1A) and Rb play important roles in cell senescence, and determine whether cells are apoptotic or senescent (71). The ATM gene is an important component of the DNA damage checkpoint pathway, which is critical in cell cycle regulation, DNA damage response and repair (80). The loss of ATM leads to telomere shortening and damage. When DNA is damaged, ATM is activated, and induces the phosphorylation of downstream proteins such as checkpoint kinase 1 (Chk1), Chk2 and cell division 
cycle. This regulates the cell cycle checkpoints, so that DNA damage is repaired (81).

The p53 gene is important in cell carcinogenesis, senescence, apoptosis and gene repair (82). When cells are exposed to external stimuli that induce DNA damage, such as chemotherapy drugs, ionizing radiation, gene mutation or telomerase shorting, the p53 gene is activated (83). p53 activates p21, which inhibits CDK1, causing cells to be arrested in the $\mathrm{G}_{2} / \mathrm{M}$ phase and decreasing the phosphorylation level of $\mathrm{pRb}$ by inhibiting the activity of CDK2 and CDK4. This prevents cells from entering the $\mathrm{S}$ phase, and ultimately leads to cell senescence (Fig. 2). In one study, mice that were genetically engineered to express altered isoforms of p53 with increased activity were shown to be resistant to cancer (84). In human and mouse cells, inactivation of the p53-p21 pathway leads to cells escaping senescence (85). The knockdown of p53 or p21 reduced the drug-induced senescence of HCT116 cell line several folds, and the same phenomenon was observed when p53 expression was suppressed in HT1080 fibrosarcoma cells $(86,87)$. Genome-wide analysis has demonstrated that the loss of $\mathrm{p} 16^{\mathrm{INK} 4 \mathrm{a}}$ expression and/or p 53 function is the most common genetic event in human cancers, and may enable cancers to evade senescence (88).

$p 16^{I N K 4 a}$ and $p R b . \mathrm{P} 16^{\text {INK4a }}$ affects the process of senescence in tumor cells and is recognized as a tumor suppressor and biomarker of senescence (89). $\mathrm{p}^{\mathrm{INK} 4 \mathrm{a}}$ is an upstream regulator of $\mathrm{pRb}$, which accelerates the degradation of phosphorylated $\mathrm{pRb}$, activates the E2 factor (E2F) family of transcription factors, arrests cells at the transition from the $G_{1}$ phase into the $\mathrm{S}$ phase and leads to cell senescence and apoptosis (90). $\mathrm{Rb}$ is a major tumor suppressor protein that serves a key role in the induction of cellular senescence and is the major substrate of CDK4/6 (91). Rb inhibits E2F regulatory factors by binding to them and shielding their transcriptional activation domains (92). When the cell genome or epigenome is damaged, the DNA damage response system is activated, which leads to the activation of protein kinase $\mathrm{C}$ and increased levels of ROS, which ultimately increase the expression level of p16 $6^{\mathrm{INK} 4 \mathrm{a}}(93)$. $\mathrm{p}^{6^{\mathrm{INK} 4 \mathrm{a}}}$ activates the $\mathrm{pRb}$ tumor suppressor and inhibits cell proliferation (Fig. 3) (94). A study demonstrated that activation of the $\mathrm{p} 16^{\text {INK4a }}$-pRb pathway was critical for the development of senescence in most human cell lines (95). The expression of $\mathrm{p} 16^{\mathrm{INK} 4 \mathrm{a}}$ is low or undetectable in young, healthy organisms, but increases exponentially in most aged tissues with senescence $(96,97)$.

ADP-ribosylation factor (ARF), double minute 2 (Mdm2) and p53. P14 (ARF) is one of the two proteins encoded by the CDKN2A, the other of which is $\mathrm{p}^{\mathrm{INK} 4 \mathrm{a}}$, and is an important inducer of cellular senescence (39). The p14 (ARF) protein is expressed at low levels in normal cells, but is markedly increased as the cells reach senescence. P14 (ARF) blocks cells in the $G_{1}$ and $G_{2} / M$ phases mainly through the p53 pathway, leading to cell senescence or apoptosis. It has been shown that when the $\mathrm{p} 16^{\mathrm{INK} 4 \mathrm{a}}$ gene is knocked out, mice are prone to developing tumors (35). It was initially considered that the deletion of $\mathrm{p}^{16^{\mathrm{INK} 4 a}}$ was responsible for disturbing of the cell senescence pathway; however, it has since been demonstrated that ARF-negative mice with normal expression levels of p16 $6^{\mathrm{INK} 4 \mathrm{a}}$ exhibit the same phenotype as those with $\mathrm{p} 16^{\mathrm{INK} 4 \mathrm{a}}$ deletion (94). Mdm2, also known as Hdm2, is a proto-oncogene in human tissues, which induces the degradation of $\mathrm{p} 53$ protein and inhibits its transcriptional activity. In particular, Mdm2 specifically binds to 553 , thereby inhibiting its transcriptional activity and promoting its extracellular transport, resulting in the inactivation of the p53 protein (98). Transcription of the Mdm2 gene is regulated by a p53 transcriptional domain and the RAF-MEK-MAP kinase signal transduction pathway. The upregulation of Mdm2 by the RAF-MEK-MAP kinase pathway has been shown to decrease p53-mediated apoptosis (99-101). The exogenous expression of ARF stabilizes p53, promotes 553 transcription, $\mathrm{p} 21^{\mathrm{WAF} 1 / \mathrm{CIP} 1}$ expression and activation of the p53-mediated apoptotic pathway, leading to apoptosis or premature senescence. In the absence of stimulation, p53 can promote the expression of Mdm2 while, conversely, $\mathrm{Mdm} 2$ reduces the activity of p53. p21 is downstream of p53, and its expression blocks progression of the cell cycle, promotes apoptosis and increases the sensitivity of tumor cells to chemotherapy (102). Mdm2 promotes the proteasome-mediated degradation of $\mathrm{p} 21$ and also reduces the stability of p21 by binding with it. When Mdm2 expression is downregulated, the expression of p21 protein increases (Fig. 4). Research has focused on investigating the involvement of the ARF-Mdm2-p53-p21 pathway in natural states as well as those involving premature senescence (103). Notably, one study showed that the loss of p14 (ARF) expression in patients with prostate cancer was positively associated with an increased risk of disease recurrence and metastatic disease (104).

S-phase kinase-associated protein 2 (Skp2) and p27. Skp2 is a member of the F-box family, which mediates cell cycle regulation and cell proliferation by degrading cell cycle regulatory proteins, including p27, p21, p53, cyclin A, cyclin E and cyclin D. The Skp2 gene is an important regulator of the cell cycle, which interacts with the S-phase kinase cyclin A-CDK2 (cyclin dependent kinase 2) complex. The expression levels of Skp2 are very low in the $G_{0} / G_{1}$ phase, but increase markedly in the $\mathrm{S}$ phase. An important substrate of Skp2 in the cell division cycle is p27 (105). p27 is an important member of the CDK family; $\mathrm{p} 27^{\mathrm{kip} 1}$ is a protein encoded by the CDKN1B gene. As a negative regulator of the cell cycle, p $27^{\mathrm{kipl}}$ inhibits the activity of CDK complexes to coordinate the cell cycle, DNA replication and DNA repair $(106,107)$. In a study in which 68 cases of non-small cell lung cancer tissues were compared with normal bronchial epithelial cells using tissue microarrays and immunohistochemistry, the results revealed that Skp2 was only expressed in the lung cancer tissues while p $27^{\mathrm{kip} 1}$ was expressed in both normal bronchial epithelial cells and lung cancer cells (108). In addition, the expression of p2 $7^{\mathrm{kip} 1}$ was found to be significantly downregulated in Skp2-positive cells and negatively correlated with Skp2 expression. In another study, Shapira et al (109) analyzed the expression of Skp2 and p $27^{\mathrm{kipl}}$ in the tissue sections of 80 patients with colorectal tumors using immunohistochemistry, and found that Skp2 overexpression was significantly associated with the loss of p2 $7^{\text {kipl }}$ expression and cell differentiation.

Skp2 may contribute to a malignant phenotype, and the overexpression of Skp2 protein results in the accelerated hydrolysis of p27 and deterioration of tumor cells (110). Since 


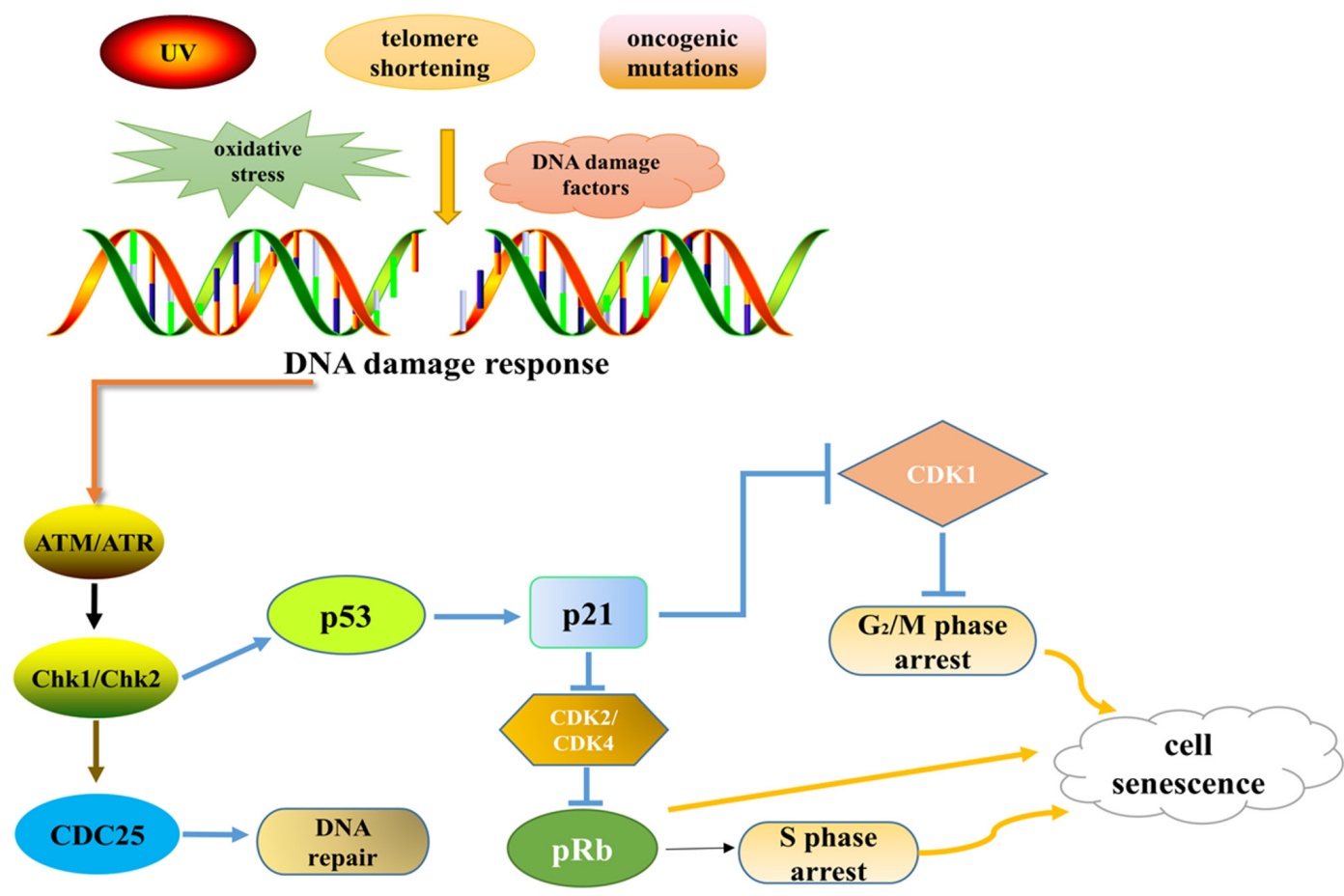

Figure 2. Various stimuli initiate DNA damage repair. ATM is activated, then the downstream proteins Chk1 and Chk2 are phosphorylated. The gene p53 then activates p21, which in turn inhibits the cell cycle at the G2/M phase by inhibiting CDK1 and also reduces the phosphorylation of pRb by inhibiting the activity of CDK2 and CDK4. This leads the cells to be arrested in the $\mathrm{S}$ phase. The downstream CDC25 family members are phosphorylated to regulate cell cycle checkpoints. ATM, ataxia telangiectasia mutated; ATR, ataxia telangiectasia and Rad3-related; Chk, checkpoint kinase; CDK, cyclin-dependent kinase; $\mathrm{CDC}$, cell division cycle; $\mathrm{pRb}$, retinoma inhibitory protein.

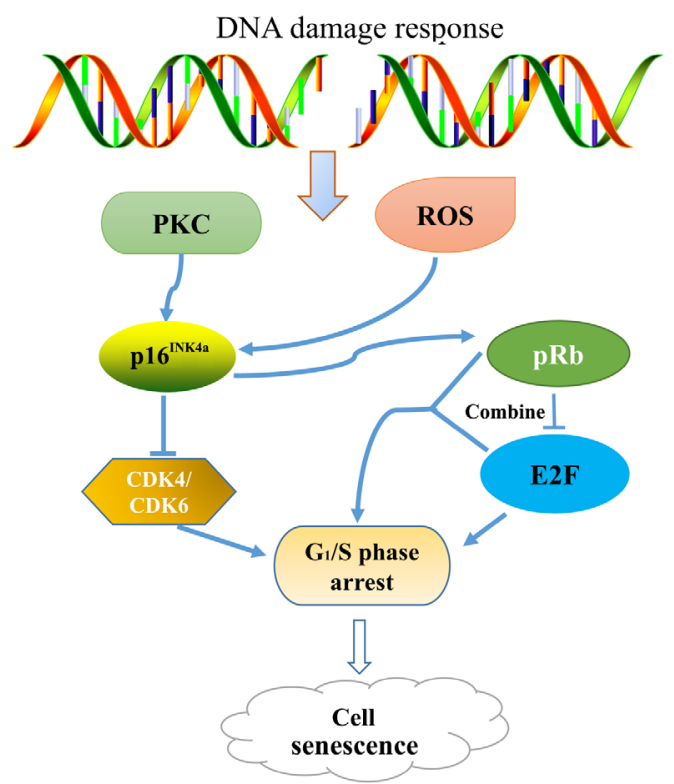

Figure 3. Cell genome or epigenome damage activates DNA damage responses, which leads to the activation of PKC and increases ROS production. This ultimately increases the expression of $\mathrm{p} 16^{\mathrm{INK} 4 \mathrm{a}}$, which then activates pRb. pRb inhibits E2F regulatory factors by binding to E2F, shielding its transcriptional activation domain, which results in cells being arrested in the $\mathrm{G}_{1} / \mathrm{S}$ phase. PKC, protein kinase $\mathrm{C}$; ROS, reactive oxygen species; $\mathrm{p} 16^{\mathrm{INK} 4 \mathrm{a}}$, CDK inhibitor $2 \mathrm{~A} ; \mathrm{pRb}$, retinoma inhibitory protein; E2F, E2 factor; CDK, cyclin-dependent kinase.

Skp2 can degrade $\mathrm{p} 27^{\mathrm{kip} 1}$ and promote tumor development, interference with the Skp2-p2 $7^{\text {kipl }}$ pathway may induce tumor senescence (111).

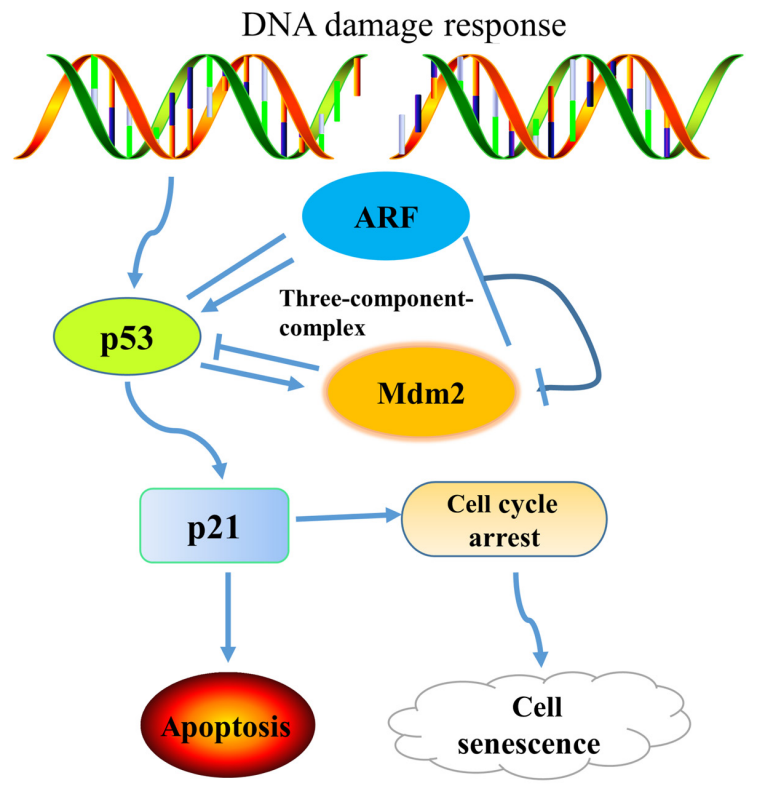

Figure 4. ARF, through p53, blocks cells in the G1 and G2/M phases, leading to cell senescence or apoptosis. Mdm2 mediates the degradation of p53 protein and inhibits the transcriptional activity of p53. p53 binds to Mdm2 and p53 also promotes the expression of Mdm2. p53 activates p21, blocks cell cycle progression and promotes apoptosis. ARF, ADP-ribosylation factor; Mdm2, double minute 2 .

Lamin B receptor $(L B R)$. The LBR is an integral membrane protein of the interphase nuclear envelope. Its $\mathrm{N}$-terminus protrudes into the nucleoplasm where it binds to lamin B and heterochromatin; these interactions are disrupted during 
mitosis (112). A number of studies have indicated that chromatin and chromatin proteins are involved in cellular senescence $(113,114)$. For example, the altered expression of lamins $\mathrm{A} / \mathrm{C}$ and $\mathrm{B}$, which form the nuclear lamina, as well as altered heterochromatin structures have been observed in senescent cells $(115,116)$. In addition, the expression of lamin B1 (LB1) in WI-38 cells was found to decrease during cellular senescence, and the silencing of LB1 slowed the proliferation of these cells and induced premature senescence. These effects were accompanied by a reduction in p53-dependent ROS, which was repaired by growth under hypoxic conditions (15).

In addition to the aforementioned senescent pathways, studies have demonstrated that inhibition of the ERK and AKT pathways can reduce the number of senescent cells, with ERK and AKT potentially acting through the ETS variant transcription factor 6 and forkhead box O1 genes (117-120). As such, drugs that target and disrupt downstream effectors of ERK and AKT have been proposed as new therapeutic methods. It has also been demonstrated that oxytocin can alleviate cell senescence through ERK/nuclear factor erythroid 2-related factor $2(\mathrm{NrF} 2)$ signaling; this implies that interference with the ERK/NrF2 pathway may induce cell senescence (121). Furthermore, the inhibition of mTORC1 has been shown to prolong the lifespan of yeast, worms, fruit flies and some mice, suggesting that mTORC1 may also be a novel target for inducing cell senescence and treating various types of cancer (122).

\section{Conclusions}

Cellular senescence and apoptosis are two equally important endpoints when cells respond to stress. As senescence acts as a major tumor suppressor mechanism, it has a number of advantages over apoptosis when dealing with damaged cells. While apoptosis permanently removes cells, senescence arrests them in a functional but non-dividing state, which may provide a persistent signal of oncogenic stress and thereby promote immune surveillance (123). The absence of senescence or apoptosis leads to treatment failure. A number of pathways have been found to activate senescence; however, the phenomenon is interesting in that although chemotherapeutic drugs induce tumor cell senescence, they also promote tumor progression by inducing the secretion of certain matrix metalloproteinases, growth factors and cytokines (12), which may lead to tissue remodeling, organ senescence and many age-related diseases. Processes such as cellular senescence and telomere shortening, which protect against cancer, may accelerate the aging process. Various diseases have been found to have an association with cell senescence, including tumors, idiopathic pulmonary fibrosis, hypertension, Parkinson's disease and diabetes.

A number of pathways are shared between the initiation of cell senescence and tumorigenesis in wound healing and cancer development, such as the activation of proto-oncogenes (124). Cell senescence and tumorigenesis have incidence rates that increase with age. The transient presence of senescent cells is beneficial during normal tissue repair, but the accumulation of these cells can have an adverse effect on local tissue homeostasis due to their pro-inflammatory properties (125-130). Even though senescence strongly inhibits tumorigenesis when initially induced (131-135), the prolonged presence of senescent cells is often associated with malignant cells and supports the expansion of tumors (69). Therefore, whether cell senescence promotes or inhibit tumors varies according to the stage of occurrence, the genetic background and the tissue. Cellular senescence prevents the development of tumors in the early stages of life, but also results in the deterioration of bodily processes. At later life stages, cellular senescence drives the occurrence of a senescence phenotype and age-associated diseases, including various degenerative diseases and a range of hyperplastic diseases. SASP-associated proteins have conflicting effects on cells within the body, indicating that cellular senescence has both favorable and unfavorable consequences during the development of cancer $(69,136,137)$. These proteins inhibit the development of tumor cells and remove abnormal and damaged cells from the body. In addition, senescent cells induce paracrine senescence in neighboring cells through the SASP, which acts as a barrier against tumor growth. By contrast, the SASP promotes the occurrence and development of tumors under certain physiological conditions, by making tumor cells tolerant to chemotherapeutic drugs (138). Further studies are required to investigate how the senescence of tumor cells can be induced or inhibited during treatment. However, the production of WNT16B and secreted frizzled related protein produced in an aged or genotoxin-treated tumor microenvironment has been found to protect cancer cells from chemotherapy in a paracrine manner $(139,140)$.

Although the inhibition of telomerase activity and induction of tumor cell senescence is a theoretically feasible approach for the treatment of tumors, certain issues must be overcome for its practical application. In particular, the telomerase activity in certain tumors is very low, and thus the inhibition of telomerase activity may not be effective for these tumors. Conversely, some normal cells possess telomerase activity $(141,142)$. In such cases, the inhibition of telomerase activity may cause adverse effects and undesirable results.

Senescence serves as a new strategy for the prevention tumors and their treatment. However, it would be beneficial to identify means for inhibiting the senescence of normal cells and prolonging life span whilst also promoting the senescence of tumor cells to treat cancer. In addition, the achievement of an effective balance between the reduction of abnormal proliferation and slowing down of senescence is important, to make good use of the double-edged sword of cellular senescence.

\section{Acknowledgements}

Not applicable.

\section{Funding}

This review was supported by Yunnan Fundamental Research Projects (grant no. 202001AU070141) and Yunnan Key Laboratory of Pharmacology for Natural Products Open grant (grant no. 2019G005).

\section{Availability of data and materials}

All data generated or analyzed during this study are included in this published article. 


\section{Authors' contributions}

GW, YJ and CQ designed and conceived the review and contributed to critical reading of the manuscript and editing. $\mathrm{XC}, \mathrm{YL}$ and $\mathrm{JZ}$ participated in drafting the manuscript and performed the literature review. GW and YJ confirm the authenticity of all the raw data. All authors read and approved the final manuscript.

\section{Ethics approval and consent to participate}

Not applicable.

\section{Patient consent for publication}

Not applicable.

\section{Competing interests}

The authors declare that they have no competing interests.

\section{References}

1. Hayflick L and Moorhead PS: The serial cultivation of human diploid cell strains. Exp Cell Res 25: 585-621, 1961

2. van Deursen JM: The role of senescent cells in ageing. Nature 509: 439-446, 2014

3. He S and Sharpless NE: Senescence in health and disease. Cell 169: 1000-1011, 2017.

4. te Poele RH, Okorokov AL, Jardine L, Cummings J and Joel SP: DNA damage is able to induce senescence in tumor cells in vitro and in vivo. Cancer Res 62: 1876-1883, 2002.

5. Wang Z, Liu H and Xu C: Cellular senescence in the treatment of ovarian cancer. Int J Gynecol Cancer 28: 895-902, 2018.

6. Saretzki G and Von Zglinicki T: Replicative aging, telomeres, and oxidative stress. Ann N Y Acad Sci 959: 24-29, 2002

7. Feng C, Yang M, Zhang Y, Lan M, Huang B, Liu H and Zhou Y: Cyclic mechanical tension reinforces DNA damage and activates the $\mathrm{p} 53-\mathrm{p} 21-\mathrm{Rb}$ pathway to induce premature senescence of nucleus pulposus cells. Int J Mol Med 41: 3316-3326, 2018.

8. Chandeck C and Mooi WJ: Oncogene-induced cellular senescence. Adv Anat Pathol 17: 42-48, 2010.

9. Falandry C, Bonnefoy M, Freyer G and Gilson E: Biology of cancer and aging: A complex association with cellular senescence. J Clin Oncol 32: 2604-2610, 2014.

10. Baeeri M, Bahadar H, Rahimifard M, Navaei-Nigjeh M, Khorasani R, Rezvanfar MA, Gholami M and Abdollahi M: $\alpha$-Lipoic acid prevents senescence, cell cycle arrest, and inflammatory cues in fibroblasts by inhibiting oxidative stress. Pharmacol Res 141: 214-223, 2019.

11. Campisi J: Senescent cells, tumor suppression, and organismal aging: Good citizens, bad neighbors. Cell 120: 513-522, 2005.

12. Zhu Y, Armstrong JL, Tchkonia T and Kirkland JL: Cellular senescence and the senescent secretory phenotype in age-related chronic diseases. Curr Opin Clin Nutr Metab Care 17: 324-328, 2014.

13. Narita M, Nũnez S, Heard E, Narita M, Lin AW, Hearn SA, Spector DL, Hannon GJ and Lowe SW: Rb-mediated heterochromatin formation and silencing of E2F target genes during cellular senescence. Cell 113: 703-716, 2003

14. Georgakopoulou EA, Tsimaratou K, Evangelou K, Fernandez Marcos PJ, Zoumpourlis V, Trougakos IP, Kletsas D, Bartek J, Serrano Mand Gorgoulis VG: Specific lipofuscin staining as a novel biomarker to detect replicative and stress-induced senescence. A method applicable in cryo-preserved and archival tissues. Aging (Albany NY) 5: 37-50, 2013.

15. Shimi T, Butin-Israeli V, Adam SA, Hamanaka RB, Goldman AE, Lucas CA, Shumaker DK, Kosak ST, Chandel NS and Goldman RD: The role of nuclear lamin B1 in cell proliferation and senescence. Genes Dev 25: 2579-2593, 2011.

16. Swanson EC, Manning B, Zhang H and Lawrence JB: Higher-order unfolding of satellite heterochromatin is a consistent and early event in cell senescence. J Cell Biol 203: 929-942, 2013.
17. Faget DV, Ren $\mathrm{Q}$ and Stewart SA: Unmasking senescence: Context-dependent effects of SASP in cancer. Nat Rev Cancer 19: 439-453, 2019.

18. Qu K, Lin T, Wei J, Meng F, Wang Z, Huang Z, Wan Y, Song S, Liu S, Chang H, et al: Cisplatin induces cell cycle arrest and senescence via upregulating P53 and P21 expression in HepG2 cells. Nan Fang Yi Ke Da Xue Xue Bao 33: 1253-1259, 2013.

19. Yao GD, Yang J, Li Q, Zhang Y, Qi M, Fan SM, Hayashi T, Tashiro S, Onodera S and Ikejima T: Activation of p53 contributes to pseudolaric acid B-induced senescence in human lung cancer cells in vitro. Acta Pharmacol Sin 37: 919-929, 2016.

20. Zhang JW, Zhang SS, Song JR, Sun K, Zong C, Zhao QD, Liu WT, Li R, Wu MC and Wei LX: Autophagy inhibition switches low-dose camptothecin-induced premature senescence to apoptosis in human colorectal cancer cells. Biochem Pharmacol 90: 265-275, 2014.

21. Shtutman M, Chang BD, Schools GP and Broude EV: Cellular model of p21-induced senescence. Methods Mol Biol 1534: 31-39, 2017.

22. Rodenak-Kladniew B, Castro A, Stärkel P, De Saeger C, García de Bravo $\mathrm{M}$ and Crespo R: Linalool induces cell cycle arrest and apoptosis in HepG2 cells through oxidative stress generation and modulation of Ras/MAPK and Akt/mTOR pathways. Life Sci 199: 48-59, 2018.

23. Ewald JA, Desotelle JA, Wilding G and Jarrard DF: Therapy-induced senescence in cancer. J Natl Cancer Inst 102: 1536-1546, 2010

24. Geng YQ, Guan JT, Xu XH and Fu YC: Senescence-associated beta-galactosidase activity expression in aging hippocampal neurons. Biochem Biophys Res Commun 396: 866-869, 2010.

25. Aird KM and Zhang R: Detection of senescence-associated heterochromatin foci (SAHF). Methods Mol Biol 965: 185-196, 2013.

26. Bernardes de Jesus B and Blasco MA: Assessing cell and organ senescence biomarkers. Circ Res 111: 97-109, 2012.

27. Park CW, Bak Y, Kim MJ, Srinivasrao G, Hwang J, Sung NK, Kim BY, Yu JH, Hong JT and Yoon DY: The novel small molecule STK899704 promotes senescence of the human A549 NSCLC cells by inducing DNA damage responses and cell cycle arrest. Front Pharmacol 9: 163, 2018.

28. Shi J, Pang L and Jiao S: The response of nucleus pulposus cell senescence to static and dynamic compressions in a disc organ culture. Biosci Rep 38: BSR20180064, 2018.

29. Nadeau S, Cheng A, Colmegna I and Rodier F: Quantifying senescence-associated phenotypes in primary multipotent mesenchymal stromal cell cultures. Methods Mol Biol 2045: 93-105, 2019.

30. Bernhart E, Damm S, Heffeter P, Wintersperger A, Asslaber M, Frank S, Hammer A, Strohmaier H, DeVaney T, Mrfka M, et al: Silencing of protein kinase D2 induces glioma cell senescence via p53-dependent and -independent pathways. Neuro Oncol 16: 933-945, 2014.

31. Matjusaitis M, Chin G, Sarnoski EA and Stolzing A: Biomarkers to identify and isolate senescent cells. Ageing Res Rev 29: 1-12, 2016.

32. Aravinthan A, Mells G, Allison M, Leathart J, Kotronen A, Yki-Jarvinen H, Daly AK, Day CP, Anstee QM and Alexander G: Gene polymorphisms of cellular senescence marker p21 and disease progression in non-alcohol-related fatty liver disease. Cell Cycle 13: 1489-1494, 2014

33. Sasaki M, Kuo FY, Huang CC, Swanson PE, Chen CL, Chuang JH and Yeh MM: Increased expression of senescence-associated cell cycle regulators in the progression of biliary atresia: An immunohistochemical study. Histopathology 72: 1164-1171, 2018.

34. Marcoux S, Le ON, Langlois-Pelletier C, Laverdière C, Hatami A, Robaey P and Beauséjour CM: Expression of the senescence marker p16INK4a in skin biopsies of acute lymphoblastic leukemia survivors: A pilot study. Radiat Oncol 8: 252, 2013.

35. Pare R, Shin JS and Lee CS: Increased expression of senescence markers p14 (ARF) and p16(INK4a) in breast cancer is associated with an increased risk of disease recurrence and poor survival outcome. Histopathology 69: 479-491, 2016.

36. Valdiglesias V, Giunta S, Fenech M, Neri M and Bonassi S: $\gamma-\mathrm{H} 2 \mathrm{AX}$ as a marker of DNA double strand breaks and genomic instability in human population studies. Mutat Res 753: 24-40, 2013.

37. Noren Hooten $\mathrm{N}$ and Evans MK: Techniques to induce and quantify cellular senescence. J Vis Exp: 55533, 2017 doi: $10.3791 / 55533$ 
38. Ko A, Han SY, Choi CH, Cho H, Lee MS, Kim SY, Song JS Hong KM, Lee HW, Hewitt SM, et al: Oncogene-induced senescence mediated by c-Myc requires USP10 dependent deubiquitination and stabilization of p14ARF. Cell Death Differ 25: 1050-1062, 2018.

39. Salama RH, Sayed ZEA, Ashmawy AM, Elsewify WA, Ezzat GM, Mahmoud MA, Alsanory AA and Alsanory TA: Interrelations of apoptotic and cellular senescence genes methylation in inflammatory bowel disease subtypes and colorectal carcinoma in Egyptians patients. Appl Biochem Biotechnol 189: 330-343, 2019.

40. Hernandez-Segura A, de Jong TV, Melov S, Guryev V, Campisi J and Demaria M: Unmasking transcriptional heterogeneity in senescent cells. Curr Biol 27: 2652-2660.e4, 2017.

41. Özcan S, Alessio N, Acar MB, Mert E, Omerli F, Peluso G and Galderisi U: Unbiased analysis of senescence associated secretory phenotype (SASP) to identify common components following different genotoxic stresses. Aging (Albany NY) 8 : $1316-1329,2016$

42. Lim S and Kaldis P: Cdks, cyclins and CKIs: Roles beyond cell cycle regulation. Development 140: 3079-3093, 2013.

43. Sage J, Attardi L and Dyke TV: Roles of p53 and pRB tumor suppressor networks in human cancer: Insight from studies in the engineered mouse. Genetically Engineered Mice Cancer Res: 293-308, 2012

44. Chellappan SP, Hiebert S, Mudryj M, Horowitz JM and Nevins JR: The E2F transcription factor is a cellular target for the RB protein. Cell 65: 1053-1061, 1991.

45. Was H, Czarnecka J, Kowalczyk A, Barszcz K, Bernas T, Piwocka K and Kaminska B: Some chemotherapeutics-treated colon cancer cells display a specific phenotype being a combination of stem-like and senescent cell features. Cancer Biol Ther 19: 63-75, 2017.

46. Mao Z, Ke Z, Gorbunova V and Seluanov A: Replicatively senescent cells are arrested in G1 and G2 phases. Aging (Albany NY) 4: 431-435, 2012.

47. Tao YF, Wang NN, Xu LX, Li ZH, Li XL, Xu YY, Fang F, Li M, Qian GH, Li YH, et al: Molecular mechanism of $\mathrm{G}_{1}$ arrest and cellular senescence induced by LEE011, a novel CDK4/CDK6 inhibitor, in leukemia cells. Cancer Cell Int 17: 35, 2017

48. Vijayaraghavan S and Keyomarsi K: An intact G1/S checkpoint determines response to CDK4/6 inhibitor in breast cancer. Cancer Res 76: 2989, 2016.

49. Vijayaraghavan S and Keyomarsi K: Abstract P5-08-02: Inhibition of CDK4/6 induces senescence and autophagy in ER positive breast cancers. Cancer Res 75: P5-08-02, 2015

50. Nelson DM, McBryan T, Jeyapalan JC, Sedivy JM and Adams PD: A comparison of oncogene-induced senescence and replicative senescence: Implications for tumor suppression and aging. Age (Dordr) 36: 9637, 2014

51. Zhu Y, Liu X, Ding X, Wang F and Geng X: Telomere and its role in the aging pathways: Telomere shortening, cell senescence and mitochondria dysfunction. Biogerontology 20: 1-16, 2019.

52. Artandi SE and DePinho RA: Role of telomeres and telomerase in cancer. Carcinogenesis 31: 9-18, 2010.

53. Shitara S, Kakeda M, Nagata K, Hiratsuka M, Sano A, Osawa K, Okazaki A, Katoh M, Kazuki Y, Oshimura M and Tomizuka K: Telomerase-mediated life-span extension of human primary fibroblasts by human artificial chromosome (HAC) vector. Biochem Biophys Res Commun 369: 807-811, 2008.

54. Kim NW, Piatyszek MA, Prowse KR, Harley CB, West MD Ho PL, Coviello GM, Wright WE, Weinrich SL and Shay JW: Specific association of human telomerase activity with immortal cells and cancer. Science 266: 2011-2015, 1994

55. Barma DK, Elayadi A, Falck JR and Corey DR: Inhibition of telomerase by BIBR 1532 and related analogues. Bioorg Med Chem Lett 13: 1333-1336, 2003.

56. Hájek M, Matulová N, Votruba I, Holý A and Tloust'ová E: Inhibition of human telomerase by diphosphates of acyclic nucleoside phosphonates. Biochem Pharmacol 70: 894-900, 2005

57. Ji XM, Xie CH, Fang MH, Zhou FX, Zhang WJ, Zhang MS and Zhou YF: Efficient inhibition of human telomerase activity by antisense oligonucleotides sensitizes cancer cell storadiotherapy. Acta Pharmacol Sin 27: 1185-1191, 2006.

58. Kondo Y and Kondo S: Telomerase RNA inhibition using antisense oligonucleotide against human telomerase RNA linked to a 2',5'-Oligoadenylate. Methods Mol Biol 405: 97-112, 2007.

59. Shammas MA, Simmons CG, Corey DR and Shmookler Reis RJ: Telomerase inhibition by peptide nucleic acids reverses 'immortality' of transformed human cells. Oncogene 18: 6191-6200, 1999.
60. Pascolo E, Wenz C, Lingner J, Hauel N, Priepke H, Kauffmann I, Garin-Chesa P, Rettig WJ, Damm K and Schnapp A: Mechanism of human telomerase inhibition by BIBR1532, a synthetic, non-nucleosidic drug candidate. J Biol Chem 277: 15566-15572, 2002.

61. Leão R, Apolónio JD, Lee D, Figueiredo A, Tabori U and Castelo-Branco P: Mechanisms of human telomerase reverse transcriptase (hTERT) regulation: Clinical impacts in cancer. J Biomed Sci 25: 22, 2018.

62. Reczek CR and Chandel NS: ROS promotes cancer cell survival through calcium signaling. Cancer Cell 33: 949-951, 2018.

63. Zhang W, Huang C, Sun A, Qiao L, Zhang X, Huang J, Sun X, Yang X and Sun S: Hydrogen alleviates cellular senescence via regulation of ROS/p53/p21 pathway in bone marrow-derived mesenchymal stem cells in vivo. Biomed Pharmacother 106: 1126-1134, 2018.

64. Zheng H, Huang Q, Huang S, Yang X, Zhu T, Wang W, Wang H, He S, Ji L, Wang Y, et al: Senescence inducer Shikonin ROS-dependently suppressed lung cancer progression. Front Pharmacol 9: 519, 2018.

65. Chen Q, Fischer A, Reagan JD, Yan LJ and Ames BN: Oxidative DNA damage and senescence of human diploid fibroblast cells. Proc Natl Acad Sci USA 92: 4337-4341, 1995.

66. Pan Jing CJ: Advances in study of the mechanisms of cellular senescence. J Pathogen Biol 10: 672-673, 2015.

67. Probin V, Wang Y and Zhou D: Busulfan-induced senescence is dependent on ROS production upstream of the MAPK pathway. Free Radic Biol Med 42: 1858-1865, 2007.

68. Mirzayans R, Andrais B, Kumar P and Murray D: Significance of Wild-type p53 signaling in suppressing apoptosis in response to chemical genotoxic agents: Impact on chemotherapy outcome. Int J Mol Sci 18: 928, 2017.

69. Campisi J: Aging, cellular senescence, and cancer. Annu Rev Physiol 75: 685-705, 2013.

70. Driscoll DL, Chakravarty A, Bowman D, Shinde V, Lasky K, Shi J, Vos T, Stringer B, Amidon B, D'Amore N and Hyer ML: Plk1 inhibition causes post-mitotic DNA damage and senescence in a range of human tumor cell lines. PLoS One 9: e111060, 2014

71. Klement $\mathrm{K}$ and Goodarzi AA: DNA double strand break responses and chromatin alterations within the aging cell. Exp Cell Res 329: 42-52, 2014

72. Yanai M, Makino H, Ping B, Takeda K, Tanaka N, Sakamoto T, Yamaguchi K, Kodani M, Yamasaki A, Igishi T and Shimizu E: DNA-PK inhibition by NU7441 enhances Chemosensitivity to topoisomerase inhibitor in non-small cell lung carcinoma cells by blocking DNA damage repair. Yonago Acta Med 60: 9-15, 2017.

73. Robles SJ, Buehler PW, Negrusz A and Adami GR: Permanent cell cycle arrest in asynchronously proliferating normal human fibroblasts treated with doxorubicin or etoposide but not camptothecin. Biochem Pharmacol 58: 675-685, 1999.

74. Zhao W, Lin ZX and Zhang ZQ: Cisplatin-induced premature senescence with concomitant reduction of gap junctions in human fibroblasts. Cell Res 14: 60-66, 2004.

75. Wang JC and Bennett M: Aging and atherosclerosis: Mechanisms, functional consequences, and potential therapeutics for cellular senescence. Circ Res 111: 245-259, 2012.

76. Finkel T, Serrano M and Blasco MA: The common biology of cancer and ageing. Nature 448: 767-774, 2007.

77. Lombard DB, Chua KF, Mostoslavsky R, Franco S, Gostissa M and Alt FW: DNA repair, genome stability, and aging. Cell 120: $0-512,2005$.

78. Benanti JA and Galloway DA: Normal human fibroblasts are resistant to RAS-induced senescence. Mol Cell Biol 24: 2842-2852, 2004.

79. Sheng GY, Yi XR, Ting JS and Ying L: Current advances of Ras induced senescence and the bypass mechanism. Progress Bioch Biophysics 43: 652-660, 2016.

80. Balmus G, Zhu M, Mukherjee S, Lyndaker AM, Hume KR, Lee J, Riccio ML, Reeves AP, Sutter NB, Noden DM, et al: Disease severity in a mouse model of ataxia telangiectasia is modulated by the DNA damage checkpoint gene Hus1. Hum Mol Genet 21: 3408-3420, 2012.

81. Yang CW, Tseng SF, Yu CJ, Chung CY, Chang CY, Pobiega S and Teng SC: Telomere shortening triggers a feedback loop to enhance end protection. Nucleic Acids Res 45: 8314-8328, 2017.

82. Lima CRDO, Rabelo RE, Vulcani VAS, Cardoso LD, de Sousa NLM and de Moura VMBD: P53 gene: Major mutations in neoplasias and anticancer gene therapy. Cienc Rural 42: 845-853, 2012 
83. Wang C, Jurk D, Maddick M, Nelson G, Martin-Ruiz C and von Zglinicki T: DNA damage response and cellular senescence in tissues of aging mice. Aging Cell 8: 311-323, 2009.

84. Tyner SD, Venkatachalam S, Choi J, Jones S, Ghebranious N, Igelmann H, Lu X, Soron G, Cooper B, Brayton C, et al: p53 mutant mice that display early ageing-associated phenotypes. Nature 415: 45-53, 2002.

85. Jiang C, Liu G, Luckhardt T, Antony V, Zhou Y, Carter AB, Thannickal VJ and Liu RM: Serpine 1 induces alveolar type II cell senescence through activating $\mathrm{p} 53-\mathrm{p} 21-\mathrm{Rb}$ pathway in fibrotic lung disease. Aging Cell 16: 1114-1124, 2017.

86. Tong Y,Zhao W, Zhou C, Wawrowsky K and Melmed S: PTTG1 attenuates drug-induced cellular senescence. PLoS One 6 : e23754, 2011

87. Ling X, Xu C, Fan C, Zhong K, Li F and Wang X: FL118 induces p53-dependent senescence in colorectal cancer cells by promoting degradation of MdmX. Cancer Res 74: 7487-7497, 2014.

88. Kandoth C, McLellan MD, Vandin F, Ye K, Niu B, Lu C, Xie M, Zhang Q, McMichael JF, Wyczalkowski MA, et al: Mutational landscape and significance across 12 major cancer types. Nature 502: 333-339, 2013.

89. Coppé JP, Rodier F, Patil CK, Freund A, Desprez PY and Campisi J: Tumor suppressor and aging biomarker p16(INK4a) induces cellular senescence without the associated inflammatory secretory phenotype. J Biol Chem 286: 36396-36403, 2011.

90. Mirzayans R, Andrais B, Hansen G and Murray D: Role of p16(INK4A) in replicative senescence and DNA damage-induced premature senescence in p53-deficient human cells. Biochem Res Int 2012: 951574, 2012.

91. Gao S, Gao Y, He HH, Han D, Han W, Avery A, Macoska JA, Liu X, Chen S, Ma F, et al: Androgen receptor tumor suppressor function is mediated by recruitment of retinoblastoma protein. Cell Rep 17: 966-976, 2016.

92.Passegué E and Wagner EF: JunB suppresses cell proliferation by transcriptional activation of p16(INK4a) expression. EMBO J 19: 2969-2979, 2000.

93. Baek MW, Cho HS, Kim SH, Kim WJ and Jung JY: Ascorbic acid induces necrosis in human laryngeal squamous cell carcinoma via ROS, PKC, and calcium signaling. J Cell Physiol 232: 417-425, 2017

94. Min EY, Kim IH, Lee J, Kim EY, Choi YH and Nam TJ: The effects of fucodian on senescence are controlled by the p16INK4a-pRb and p14Arf-p53 pathways in hepatocellular carcinoma and hepatic cell lines. Int J Oncol 45: 47-56, 2014.

95. Nakade K, Lin CS, Chen XY, Tsai MH, Wuputra K, Zhu ZW, Pan JZ and Yokoyama KK: Jun dimerization protein 2 controls hypoxia-induced replicative senescence via both the $\mathrm{p} 16^{\text {Ink4a }}-\mathrm{pRb}$ and Arf-p53 pathways. FEBS Open Bio 7 1793-1804, 2017.

96. Krishnamurthy J, Ramsey MR, Ligon KL, Torrice C, Koh A, Bonner-Weir S and Sharpless NE: p16INK4a induces an age-dependent decline in islet regenerative potential. Nature 443 453-457, 2006.

97. Da Silva-Álvarez S, Picallos-Rabina P, Antelo-Iglesias L, Triana-Martínez F, Barreiro-Iglesias A, Sánchez L and Collado M: The development of cell senescence. Exp Gerontol 128: 110742, 2019.

98. Zhao Y, Aguilar A, Bernard D and Wang S: Small-molecule inhibitors of the MDM2-p53 protein-protein interaction (MDM2 Inhibitors) in clinical trials for cancer treatment. J Med Chem 58: 1038-1052, 2015.

99. Zheng S, Huang KE, Pan YL, Zhou Y, Pan SD, Li X, Jia J, Zheng XL and Tao DY: KIT and BRAF heterogeneous mutations in gastrointestinal stromal tumors after secondary imatinib resistance. Gastric Cancer 18: 796-802, 2015.

100. Li Z, Fu J, Rew Y, Gribble MW and Medina JC: Abstract 3663 : Discovery of sulfonamide-piperidinones as potent inhibitors of the MDM2-p53 protein-protein interaction. Cancer Res 75 3663-3663, 2015.

101. Seipel K, Marques M, Sidler C, Mueller BU and Pabst T: The cellular p53 inhibitor MDM2 and the growth factor receptor FLT3 as biomarkers for treatment responses to the MDM2-inhibitor idasanutlin and the MEK1 inhibitor cobimetinib in acute myeloid leukemia. Cancers 10: 170, 2018

102. Yue Z, Rong J, Ping W, Bing Y, Xin Y, Feng LD and Yaping W: Gene expression of the p16(INK4a)-Rb and p19(Arf)-p53-p21(Cip/Waf1) signaling pathways in the regulation of hematopoietic stem cell aging by ginsenoside $\mathrm{Rg} 1$. Genet Mol Res 13: 10086-10096, 2014.
103. Wei W, Hemmer RM and Sedivy JM: Role of p14(ARF) in replicative and induced senescence of human fibroblasts. Mol Cell Biol 21: 6748-6757, 2001.

104. Pencik J, Schlederer M, Gruber W, Unger C, Walker SM, Chalaris A, Marié IJ, Hassler MR, Javaheri T, Aksoy O, et al: STAT3 regulated ARF expression suppresses prostate cancer metastasis. Nat Commun 6: 7736, 2015.

105. Hershko D, Bornstein G, Ben-Izhak O, Carrano A, Pagano M, Krausz MM and Hershko A: Inverse relation between levels of p27(Kip1) and of its ubiquitin ligase subunit Skp2 in colorectal carcinomas. Cancer 91: 1745-1751, 2001.

106. Sharma SS, Ma L and Pledger WJ: p27Kip1 inhibits the cell cycle through non-canonical G1/S phase-specific gatekeeper mechanism. Cell Cycle 14: 3954-3964, 2015.

107. Ma D, Guo D, Li W and Zhao H: Mdig, a lung cancer-associated gene, regulates cell cycle progression through p27(KIP1). Tumour Biol 36: 6909-6917, 2015 .

108. Hu X, Liu F, Jiang B and Wang Y: The expression of Skp2 in human non-small cell lung cancer and its correlation with expression of p27 protein. Zhongguo Fei Ai Za Zhi 11: 547-550, 2008 (In Chinese).

109. Shapira M, Ben-Izhak O, Linn S, Futerman B, Minkov I and Hershko DD: The prognostic impact of the ubiquitin ligase subunits Skp2 and Cks1 in colorectal carcinoma. Cancer 103: 1336-1346, 2005.

110. Hafez MM, Alhoshani AR, Al-Hosaini KA, Alsharari SD, Al Rejaie SS, Sayed-Ahmed MM and Al-Shabanah OA: SKP2/P27Kip1 pathway is associated with advanced ovarian cancer in Saudi patients. Asian Pac J Cancer Prev 16: 5807-5815, 2015.

111. Gstaiger M, Jordan R, Lim M, Catzavelos C, Mestan J, Slingerland J and Krek W: Skp2 is oncogenic and overexpressed in human cancers. Proc Natl Acad Sci USA 98: 5043-5048, 2001

112. Olins AL, Rhodes G, Welch DBM, Zwerger M and Olins DE: Lamin B receptor: Multi-tasking at the nuclear envelope. Nucleus 1: 53-70, 2010.

113. En A, Takauji Y, Ayusawa D and Fujii M: The role of lamin B receptor in the regulation of senescence-associated secretory phenotype (SASP). Exp Cell Res 390: 111927, 2020.

114. Sadaie M, Salama R, Carroll T, Tomimatsu K, Chandra T, Young AR, Narita M, Pérez-Mancera PA, Bennett DC, Chong $\mathrm{H}$, et al: Redistribution of the Lamin $\mathrm{B} 1$ genomic binding profile affects rearrangement of heterochromatic domains and SAHF formation during senescence. Genes Dev 27: 1800-1808, 2013.

115. Solovei I, Wang AS, Thanisch K, Schmidt CS, Krebs S, Zwerger M, Cohen TV, Devys D, Foisner R, Peichl L, et al: LBR and lamin $\mathrm{A} / \mathrm{C}$ sequentially tether peripheral heterochromatin and inversely regulate differentiation. Cell 152: 584-598, 2013.

116. Arai R, En A, Takauji Y, Maki K, Miki K, Fujii M and Ayusawa D Lamin B receptor (LBR) is involved in the induction of cellular senescence in human cells. Mech Ageing Dev 178: 25-32, 2019.

117. Latorre E, Ostler EL, Faragher RGA and Harries LW: FOXO1 and ETV6 genes may represent novel regulators of splicing factor expression in cellular senescence. FASEB J 33: 1086-1097, 2019.

118. He Q, Xue S, Tan Y, Zhang L, Shao Q, Xing L, Li Y, Xiang T, Luo $X$ and Ren G: Dual inhibition of Akt and ERK signaling induces cell senescence in triple-negative breast cancer. Cancer Lett 448: 94-104, 2019.

119. Lam EW, Francis RE and Petkovic M: FOXO transcription factors: Key regulators of cell fate. Biochem Soc Trans 34: 722-726, 2006

120. Clark O, Daga S and Stoker AW: Tyrosine phosphatase inhibitors combined with retinoic acid can enhance differentiation of neuroblastoma cells and trigger ERK- and AKT-dependent, p53-independent senescence. Cancer Lett 328: 44-54, 2013.

121. Wu H, Zhao J, Chen M, Wang H, Yao Q, Fan J and Zhang M: The Anti-aging effect of erythropoietin via the ERK/Nrf2-ARE pathway in aging rats. J Mol Neurosci 61: 449-458, 2017.

122. Kucheryavenko O, Nelson G, von Zglinicki T, Korolchuk VI and Carroll B: The mTORC1-autophagy pathway is a target for senescent cell elimination. Biogerontology 20: 331-335, 2019.

123. Shan HY, Bai XJ and Chen XM: Apoptosis is involved in the senescence of endothelial cells induced by angiotensin II. Cell Biol Int 32: 264-270, 2008

124. Goruppi S and Dotto GP: Mesenchymal Stroma: Primary determinant and therapeutic target for epithelial cancer. Trends Cell Biol 23: 593-602, 2013

125. Lee S and Schmitt CA: The dynamic nature of senescence in cancer. Nat Cell Biol 21: 94-101, 2019. 
126. Krizhanovsky V, Yon M and Dickins RA: Senescence of activated stellate cells limits liver fibrosis. Cell 134: 657-667, 2008.

127. Burton DGA and Krizhanovsky V: Physiological and pathological consequences of cellular senescence. Cell Mol Life Sci 71: 4373-4386, 2014.

128. Demaria M, Desprez PY, Campisi J and Velarde MC: Cell Autonomous and Non-autonomous effects of senescent cells in the skin. J Invest Dermatol 135: 1722-1726, 2015.

129. Muller M, Li Z and Maitz PKM: Pseudomonas pyocyanin inhibits wound repair by inducing premature cellular senescence: Role for p38 mitogen-activated protein kinase. Burns 35: 500-508, 2009.

130. Bitar MS, Abdel-Halim SM and Al-Mulla F: Caveolin-1/PTRF upregulation constitutes a mechanism for mediating p53-induced cellular senescence: Implications for evidence-based therapy of delayed wound healing in diabetes. Am J Physiol Endocrinol Metab 305: E951-E963, 2013.

131. Michaloglou C, Vredeveld LCW, Soengas MS, Denoyelle C, Kuilman T, van der Horst CM, Majoor DM, Shay JW, Mooi WJ and Peeper DS: BRAFE600-associated senescence-like cell cycle arrest of human naevi. Nature 436: 720-724, 2005.

132. Bartkova J, Rezaei N, Liontos M, Karakaidos P, Kletsas D, Issaeva N, Vassiliou LV, Kolettas E, Niforou K, Zoumpourlis VC, et al: Oncogene-induced senescence is part of the tumorigenesis barrier imposed by DNA damage checkpoints. Nature 444: 633-637, 2006.

133. Chen Z, Trotman LC, Shaffer D, Lin HK, Dotan ZA, Niki M, Koutcher JA, Scher HI, Ludwig T, Gerald W, et al: Crucial role of p53-dependent cellular senescence in suppression of Pten-deficient tumorigenesis. Nature 436: 725-730, 2005.

134. Braig M, Lee S, Loddenkemper C, Rudolph C, Peters AH Schlegelberger B, Stein H, Dörken B, Jenuwein T and Schmitt CA: Oncogene-induced senescence as an initial barrier in lymphoma development. Nature 436: 660-665, 2005.
135. Collado M, Gil J, Efeyan A, Guerra C, Schuhmacher AJ, Barradas M, Benguría A, Zaballos A, Flores JM, Barbacid M, et al: Tumour biology: Senescence in premalignant tumours. Nature 436: 642, 2005.

136. Campisi J: Aging and cancer: The double-edged sword of replicative senescence. J Am Geriatr Soc 45: 482-488, 1997.

137. Mavrogonatou E, Pratsinis H and Kletsas D: The role of senescence in cancer development. Semin Cancer Biol 62: 182-191, 2020.

138. Rao SG and Jackson JG: SASP: Tumor suppressor or promoter? Yes! Trends Cancer 2: 676-687, 2016.

139. Sun Y, Campisi J, Higano C, Beer TM, Porter P, Coleman I, True L and Nelson PS: Treatment-induced damage to the tumor microenvironment promotes prostate cancer therapy resistance through WNT16B. Nat Med 18: 1359-1368, 2012.

140. Sun Y, Zhu D, Chen F, Qian M, Wei H, Chen W and Xu J: SFRP2 augments WNT16B signaling to promote therapeutic resistance in the damaged tumor microenvironment. Oncogene 35: 4321-4334, 2016.

141. Yang B, Shi L, Lei J, Li B and Jin Y: Advances in optical assays for detecting telomerase activity. Luminescence 34: 136-152, 2019.

142. Yuan X, Larsson C and Xu D: Mechanisms underlying the activation of TERT transcription and telomerase activity in human cancer: Old actors and new players. Oncogene 38: 6172-6183, 2019.

This work is licensed under a Creative Commons Attribution-NonCommercial-NoDerivatives 4.0 International (CC BY-NC-ND 4.0) License. 